\title{
Entrepreneurs' Attitude toward English Proficiency of Interns of Rajamangala University of Technology Thanyaburi
}

\author{
Montchatry Ketmuni ${ }^{1}$, Piyanuch Sawatyothin ${ }^{2}$ \\ ${ }^{1,2}$ Department of Western Languages, Faculty of Liberal Arts, Rajamangala University of Technology Thanyaburi, Thailand \\ ${ }^{1}$ montchatry@rmutt.ac.th, ${ }^{2}$ piyanuch_s@rmutt.ac.th
}

\begin{abstract}
This research was funded by Faculty of Liberal Arts, Rajamangala University of Technology Thanyaburi (RMUTT). The purposes of this research were to 1) determine entrepreneurs' attitude toward English proficiency of RMUTT interns in the second semester in academic year 2016, and 2) to study the entrepreneurs' opinions for improving the content of English language courses. The 400 entrepreneurs participating RMUTT internship were selected by multi-stage sampling. The research instrument was a questionnaire $(\alpha=0.94)$. The statistics used for data analysis were frequency, percentage, mean, standard deviation, and f-test. Findings of the research revealed that the organizations moderately used English language in workplace and using English in a workplace had no significant difference among types of the organizations. Most organizations did not require English language on recruitment process. According to the entrepreneurs' opinions, all English skills of RMUTT interns were at a moderate level. The highest of each skill was listening to the supervisors' instructions with technical terms, speaking English for everyday use, reading emails or business letters, and filling in forms. The entrepreneurs recommended writing email correspondence, filling in forms, and note-taking in English. Speaking with confidence was also suggested as well as more listening and reading practice.
\end{abstract}

Index Terms

Attitude, English Proficiency, Interns, Higher Education

Article Received: 10 August 2020, Revised: 25 October 2020, Accepted: 18 November $2020 \mathrm{~m}$

\section{Introduction}

In the 21 st century, the world is fast changing with technological development affecting our livelihood. Many industries tend to reduce the production costs by using advanced technology instead of the workforce. Thailand 4.0 is an economic model in order to create a value-based economy that is driven by innovation, technology and creativity [1], so many companies tend to recruit high performing employees with multitasking skills. Therefore new graduates need to be trained to meet the needs of the employers. Beyond the professional skills, English language is an important skill as a medium for communication in the challenging world, especially for new graduates. The new graduates have to improve their English language with the main four skills: listening, reading, speaking, and writing for earning their living in the future. [2] noted the unskilled workers are less likely to have a chance of getting a job. Rajamangala University of Technology Thanyaburi (RMUTT) has been highly recognized as an educational institution having a commitment on producing "hands-on graduates" to serve the society [3]. RMUTT has continuously improved the students' English language competency with effective policies, for example, internship abroad programs, international training courses, English language learning software, etc. However, the English language development of the students will be more effective when it meets the needs of the entrepreneurs. As an educational institution, RMUTT has to plan the new strategies for the English language development to support both the entrepreneurs who recruit the RMUTT graduates and the changing world. So, this is the right time to discover where the RMUTT students are placed in the entrepreneurs' points of view in order to guide the students in a particular way, and also get insight of the current trends of skills needed in each organization and of what the entrepreneurs need right now.

\section{Research Objectives}

This research aimed to 1) determine the entrepreneurs' attitude toward English proficiency of the RMUTT interns, and 2) study the entrepreneurs' opinions for improving the content of English language courses.

\section{Research Methods}

\section{A. Research Design}

This research was a quantitative research. The samples were 400 entrepreneurs participating in the RMUTT internship in the academic year 2016 that were selected by multi-stage sampling. The research instrument was a questionnaire divided into 3 parts: the general information of respondents, the attitude of the respondents toward the English proficiency of the RMUTT interns, and the entrepreneurs' recommendations. There were 6 scales in the questionnaire; scale 5 was the interns' English skill performance was at the very good level whereas scale 1 was the interns' English skill performance should be improved, including with scale 0 was no English language skills in the workplace. The questionnaire was validated by 3 experts and its alpha coefficient was 0.94.The statistics used for data analysis were frequency, percentage, mean, standard deviation, and the one-way ANOVA F-test with Fisher's least significant difference (LSD). Beyond the determination of entrepreneurs' attitude toward the English proficiency of the RMUTT interns to identify how well the RMUTT interns use English language in the workplace, this research also tried to discover the importance of English in the 
workplace, and what kinds of English skills the entrepreneurs needed in the new era of disruptive technology.

\section{B. Research Process}

Research process of this research was separated into 7 steps, namely, propose the research proposal, review related theories and researches, gather the information of entrepreneurs, create and validate the questionnaire, collect the data, analyze the data, and discuss the results. Steps were shown in Fig. 1.

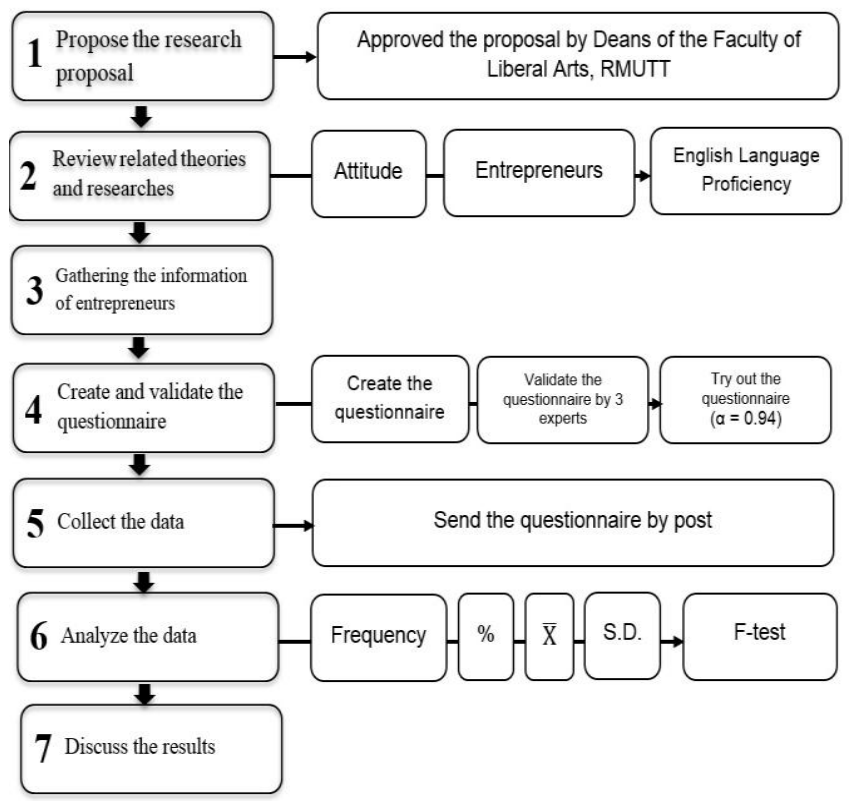

Fig.1 Research process

\section{Results}

The research results showed that 400 respondents were the internship advisors: $58.75 \%$ worked in the private sector, $22.25 \%$ worked in the public sector, $16.00 \%$ worked in the state enterprises, and $12 \%$ worked in the nonprofit organizations. The RMUTT interns assessed by the respondents were from 9 faculties: $26.25 \%$ from Faculty of Engineering, 25.25\% from Faculty of Business Administration, 14.50 from Faculty of Science and Technology, 8.00\% from Faculty of Mass Communication Technology, 7.75\% from Faculty of Liberal Arts, $7.50 \%$ from Faculty of Technical Education, $4.00 \%$ from Thai Medical College, $3.50 \%$ from Faculty of Agriculture Engineering, and 3.25\% from Faculty of Fine and Applied Arts. The respondents were asked about using the English standardized tests for recruiting the new employees, and the results showed that there were TOEIC $(4.50 \%)$, TOEFL $(0.75 \%)$, IELTS $(0.75 \%)$, others $(5.75 \%)$, and no English score used for recruiting $(88.25 \%)$.

The entrepreneurs' attitude toward overall English proficiency of the RMUTT interns was at the moderate level $(\bar{X}=3.06$, S.D. $=0.72)$. The reading skills were the highest $(\overline{\mathrm{X}}=3.13$, S.D. $=0.73)$ following by the listening skills $(\overline{\mathrm{X}}$ $=3.08$, S.D. $=0.77)$, the speaking skills $(\overline{\mathrm{X}}=3.02$, S.D. $=$ $0.64)$, and the writing skills $(\overline{\mathrm{X}}=3.00$, S.D. $=0.72)$ as shown in Table 1.
Table 1 The attitude of entrepreneurs toward RMUTT interns' English proficiency

\begin{tabular}{lcccc}
\hline \multirow{2}{*}{ English Proficiency } & $\overline{4}$ Attitude \\
\cline { 2 - 5 } & $\overline{\mathrm{X}}$ & S.D. & Levels & Ranking \\
\hline 1. Listening & 3.08 & 0.77 & Moderate & 2 \\
2. Speaking & 3.02 & 0.64 & Moderate & 3 \\
3. Reading & 3.13 & 0.73 & Moderate & 1 \\
4. Writing & 3.00 & 0.72 & Moderate & 4 \\
\hline \multicolumn{1}{c}{ Total } & 3.06 & 0.72 & Moderate \\
\hline
\end{tabular}

The research results for listening skills as shown in Table 2 indicated that all listening skills of the RMUTT interns were at a moderate level. The listening skill the most highly used in the workplace was listening to the supervisor's instructions with technical terms $(n=305)$, and the entrepreneurs' attitude toward this skill of the RMUTT interns was also the best skill among all listening skills $(\overline{\mathrm{X}}$ $=3.24$, S.D. $=0.70$ ).

Table 2 The entrepreneurs' attitude toward listening skills of the RMUTT interns

\begin{tabular}{|c|c|c|c|c|c|}
\hline \multirow{2}{*}{ Listening skills } & \multicolumn{5}{|c|}{ Attitude } \\
\hline & $\mathbf{n}$ & $\bar{x}$ & S.D. & Levels & Ranking \\
\hline 1. Listening to the customers' needs & 286 & 3.15 & 0.71 & Moderate & 2 \\
\hline 2. Listening on the phone & 273 & 3.06 & 0.71 & Moderate & 3 \\
\hline 3. Listening for note taking and fill forms & 284 & 3.04 & 0.71 & Moderate & 5 \\
\hline $\begin{array}{l}\text { 4. Listening to the supervisor's instructions } \\
\text { with technical terms }\end{array}$ & 305 & 3.24 & 0.70 & Moderate & 1 \\
\hline 5. Listening to the meeting & 291 & 2.99 & 0.66 & Moderate & 7 \\
\hline $\begin{array}{l}\text { 6. Listening to the foreign colleague } \\
\text { conversation }\end{array}$ & 266 & 3.00 & 0.76 & Moderate & 6 \\
\hline 7. Listening to media: radio, TV, etc. & 276 & 3.05 & 0.74 & Moderate & 4 \\
\hline Total & & 3.08 & 0.71 & Moderate & \\
\hline
\end{tabular}

Note: $\mathrm{n}=\mathrm{a}$ number of the entrepreneurs that used each skill

Regarding the speaking skills, the entrepreneurs' attitude toward the speaking skills of the RMUTT interns was at a moderate level. The results showed that speaking in everyday life, such as greeting, welcoming, complementing, apologizing to customers, and saying goodbye to customers was the most highly used in the workplace $(n=283)$, and this skill of the RMUTT interns was the best skill among all speaking skills $(\overline{\mathrm{X}}=3.14$, S.D. $=0.67)$ as shown in Table 3 .

Table 3 The entrepreneurs' attitude toward speaking skills of the RMUTT interns

\begin{tabular}{|c|c|c|c|c|c|}
\hline \multirow[b]{2}{*}{ Speaking skills } & \multicolumn{5}{|c|}{ Attitude } \\
\hline & n & $\overline{\mathrm{X}}$ & SD. & Levels & Ranking \\
\hline $\begin{array}{l}\text { 1. Speaking in everyday life, such as greeting, } \\
\text { welcoming, complementing, apologizing to } \\
\text { customers, and saying goodbye to customers. }\end{array}$ & 283 & 3.14 & 0.67 & Moderate & 1 \\
\hline 2. Making a conversation on the phone. & 266 & 3.05 & 0.66 & Moderate & 3 \\
\hline 3. Asking for the customers' needs & 254 & 2.98 & 0.69 & Moderate & 7 \\
\hline $\begin{array}{l}\text { 4. Giving information the working procedures, service } \\
\text { procedures, regulations, or prohibitions }\end{array}$ & 272 & 3.04 & 0.71 & Moderate & 4 \\
\hline 5. Giving directions & 282 & 3.06 & 0.67 & Moderate & 2 \\
\hline 6. Business negotiation & 260 & 2.97 & 0.71 & Moderate & 8 \\
\hline 7. Expressing the opinions in the meeting & 267 & 3.03 & 0.70 & Moderate & 5 \\
\hline 8. Oral presentation & 267 & 2.98 & 0.68 & Moderate & 6 \\
\hline 9. Talking about work with the foreign colleagues & 244 & 2.96 & 0.69 & Moderate & 9 \\
\hline Total & & 3.02 & 0.69 & Moderate & \\
\hline
\end{tabular}

Note: $\mathrm{n}=\mathrm{a}$ number of the entrepreneurs that used each skill 
The reading skills of the RMUTT interns were also at a moderate level by the entrepreneurs' attitude. The skills most highly used in the workplace were reading work manuals $(n=298)$ and reading news, announcements, or signs $(n=298)$ while the entrepreneurs thought that the RMUTT interns best performed reading emails or business emails $(\overline{\mathrm{X}}=3.21$, S.D. $=0.72)$ as shown in Table 4 .

Table 4 The entrepreneurs' attitude toward reading skills of the RMUTT interns

\begin{tabular}{lccccc}
\hline \hline \multirow{1}{*}{ Reading skills } & \multicolumn{5}{c}{ Attitude } \\
& $\mathbf{n}$ & $\bar{X}$ & SD. & Levels & Ranking \\
\hline 1. Reading work manuals & 298 & 3.13 & 0.73 & Moderate & 3 \\
2. Reading emails or business emails & 281 & 3.21 & 0.72 & Moderate & 1 \\
3. reading news, announcements, or signs & 298 & 3.11 & 0.73 & Moderate & 4 \\
4. Reading working documents & 282 & 3.19 & 0.70 & Moderate & 2 \\
5. Reading the customers' documents & 281 & 3.11 & 0.74 & Moderate & 5 \\
6. Reading minutes of meeting & 264 & 3.03 & 0.73 & Moderate & 6 \\
\hline \multicolumn{1}{c}{ Total } & & 3.13 & $\mathbf{0 . 7 3}$ & Moderate &
\end{tabular}

Note: $\mathrm{n}=\mathrm{a}$ number of the entrepreneurs that used each skill

According to the research results for writing skills in Table 5, the entrepreneurs thought that the RMUTT interns could also perform all writing skills in a moderate level. The skill most highly used in the workplace was filling forms $(n=280)$, and this skill of the RMUTT interns was the best skill among all writing skills $(\overline{\mathrm{X}}=3.05$, S.D. $=0.69)$

Table 5 The entrepreneurs' attitude toward writing skills of the RMUTT interns

\begin{tabular}{|c|c|c|c|c|c|}
\hline \multirow[b]{2}{*}{ Writing skills } & \multicolumn{5}{|c|}{ Attitude } \\
\hline & $\mathrm{n}$ & $\bar{X}$ & S.D. & Levels & Ranking \\
\hline 1. Recording the customers' information & 263 & 3.03 & 0.71 & Moderate & 3 \\
\hline 2. Filling forms & 280 & 3.05 & 0.69 & Moderate & 1 \\
\hline 3. Taking messages on the phone & 277 & 2.97 & 0.71 & Moderate & 7 \\
\hline 4. Writing and replying emails & 274 & 3.04 & 0.74 & Moderate & 2 \\
\hline 5. Writing the instructions & 279 & 3.03 & 0.74 & Moderate & 4 \\
\hline 6. Writing directions to a place & 267 & 2.99 & 0.74 & Moderate & 5 \\
\hline 7. Minute writing & 267 & 2.93 & 0.71 & Moderate & 8 \\
\hline 8. Writing work reports & 271 & 2.98 & 0.70 & Moderate & 6 \\
\hline Total & & 3.00 & 0.72 & Moderate & \\
\hline
\end{tabular}

Note: $\mathrm{n}=$ a number of the entrepreneurs that used each skill

The research hypothesis was that the different types of the entrepreneurs had the different attitude toward English proficiency of the RMUTT interns, and it was tested of the significance of difference by using the one-way ANOVA Ftest and making the pairwise comparisons with Fisher's Least Significant Difference (LSD). The testing results were shown in Table 6 and Table 7.
Table 6 The research hypothesis tested with the one-way ANOVA F-test

\begin{tabular}{|c|c|c|c|c|c|c|}
\hline English proficiency & Types of entrepreneurs & n & Mean & S.D. & $\mathrm{F}$ & Sig. \\
\hline \multirow[t]{5}{*}{ Listening skills } & Public sector & 75 & 2.75 & 0.871 & 2.052 & 1.06 \\
\hline & State enterprises & 51 & 2.57 & 0.994 & & \\
\hline & Nonprofit organizations & 9 & 3.14 & 0.746 & & \\
\hline & Private sector & 199 & 2.54 & 0.899 & & \\
\hline & Total & 334 & 2.61 & 0.909 & & \\
\hline \multirow[t]{5}{*}{ Speaking skills } & Public sector & 74 & 2.69 & 0.980 & 2.216 & .086 \\
\hline & State enterprises & 49 & 2.42 & 1.070 & & \\
\hline & Nonprofit organizations & 9 & 3.00 & 0.606 & & \\
\hline & Private sector & 189 & 2.44 & 0.933 & & \\
\hline & Total & 321 & 2.51 & 0.965 & & \\
\hline \multirow[t]{5}{*}{ Reading skills } & Public sector & 73 & 2.95 & 0.876 & 2.488 & .060 \\
\hline & State enterprises & 53 & 2.52 & 0.997 & & \\
\hline & Nonprofit organizations & 9 & 2.52 & 0.724 & & \\
\hline & Private sector & 192 & 2.70 & 0.941 & & \\
\hline & Total & 327 & 2.72 & 0.938 & & \\
\hline \multirow[t]{5}{*}{ Writing skills } & Public sector & 73 & 2.87 & 0.763 & 3.716 & $.012^{* *}$ \\
\hline & State enterprises & 54 & 2.41 & 1.011 & & \\
\hline & Nonprofit organizations & 9 & 2.58 & 0.390 & & \\
\hline & Private sector & 183 & 2.48 & 0.969 & & \\
\hline & Total & 319 & 2.56 & 0.935 & & \\
\hline \multirow[t]{5}{*}{ Overall } & Public sector & 72 & 2.84 & 0.751 & 1.942 & .123 \\
\hline & State enterprises & 48 & 2.52 & 0.914 & & \\
\hline & Nonprofit organizations & 9 & 2.81 & 0.472 & & \\
\hline & Private sector & 171 & 2.65 & 0.743 & & \\
\hline & Total & 300 & 2.68 & 0.772 & & \\
\hline
\end{tabular}

According to Table 6, the hypothesis was tested by using the one-way ANOVA F-test at the significant level of .05. The overall result found that the different types of the entrepreneurs had no different attitude toward English proficiency of the RMUTT interns at the statistically significant level of .05. Considering each skill, the different types of the entrepreneurs had no different attitude toward listening, speaking, and reading skills of the RMUTT interns; however, the different types of the entrepreneurs had the different attitude toward writing skills at the statistically significant level of .05 .

Table 7 The pairwise comparisons of writing skills with Fisher's Least Significant Difference (LSD)

\begin{tabular}{lccccc}
\hline \multirow{2}{*}{ Writing skills } & \multicolumn{5}{c}{ Pairwise comparisons (Mean Difference (I-J) } \\
\cline { 2 - 6 } & Mean & X1 & X2 & X3 & X4 \\
\hline X1 Public sector & 2.87 & - & $.47\left(^{* *}\right)$ & .29 & $.39\left(^{* *}\right)$ \\
\hline X2 State enterprises & 2.41 & & - & -.18 & -.08 \\
\hline$X 3$ Nonprofit organizations & 2.58 & & & - & .10 \\
\hline$X 4$ Private sector & 2.48 & & & & - \\
\hline${ }^{* *} \mathrm{p}<.05$ & & & & &
\end{tabular}

As seen in Table 7, the entrepreneurs in the public sector (the government agencies) had the different attitude toward writing skills of the RMUTT interns greater than the entrepreneurs in the private sector and nonprofit organizations.

However, the entrepreneurs provided some recommendations on how the students could improve listening, speaking, reading and writing skills including other recommendations for the educational institutes as shown in Table 8. 
Table 8 Entrepreneurs' recommendations

\begin{tabular}{lcc}
\hline \multicolumn{1}{c}{ Recommendations } & $\mathrm{n}$ & $\%$ \\
\hline $\begin{array}{l}\text { 1. Train the students for all four skills until the } \\
\text { students are confident and use English language } \\
\text { practically }\end{array}$ & 25 & 83.33 \\
$\begin{array}{l}\text { 2. Offer special English language courses at work } \\
\text { emphasizing foundation listening, speaking, reading, } \\
\text { and writing before internship and separate these }\end{array}$ & 20 & 66.67 \\
$\begin{array}{l}\text { courses from general English courses } \\
\text { 3. Assess the students' English language proficiency } \\
\text { before internship in order to give proper work } \\
\text { assignments }\end{array}$ & 11 & 36.67 \\
$\begin{array}{l}\text { 4. Offer courses in English for specific purposes and } \\
\text { English for presentations }\end{array}$ & 8 & 26.67 \\
\begin{tabular}{l} 
5. Set the English language proficiency testing \\
\hline
\end{tabular} & 4 & 13.33 \\
\hline
\end{tabular}

Note: $\mathrm{n}=\mathrm{a}$ number of respondents

\section{Discussions}

The research results of the entrepreneurs' attitude toward English proficiency of the RMUTT interns reflected the English language learning management meeting the stakeholders that could be discussed as follows:

1. The overall attitude of the entrepreneurs toward English proficiency of the RMUTT interns was at a moderate level; moreover, when considering each skill, it was also placed at a moderate level. All skills could be arranged in descending order by mean: listening skills, reading skills, speaking skills, and writing skills relatively. This result showed that the RMUTT interns could perform the receptive skills better than productive skills. [4] noted that the language users in any languages have greater receptive competence than productive competence. Furthermore, this might be caused by the unfamiliarity to communicate in English, the lack of using English language skills in the real situations including the differences in the fundamentals of English language skills affecting the confidence to communicate in English. [5] noted that Thailand's education system did not meet each students' individual learner needs, social needs, and country's needs. When the students graduated, they could not use English language effectively. It is related to the research recommendations of [2] that there should be more English language courses provided to prepare the Thai graduates for their future careers. Furthermore, it is supported by the entrepreneurs' recommendations that before starting the internship the students should take more English courses to improve their English skills in order to be ready for internship and these courses should be separated from the general English courses.

1.1 Listening skills of the RMUTT interns were at a moderate level, and the skill with the highest mean was listening to the manager's instructions with the technical terms. It was because the interns had the specialized knowledge in a particular discipline or profession that could transfer the information with the appropriate translation of the target language [6]. This is because professional careers need their terminology knowledge in order to understand the intricate details of work. [7] noted that the employees should improve listening skills because it was important for workplace communication that was greatly involved with terminology.
1.2. Speaking skills of the RMUTT interns were at a moderate level, and the skill with the highest mean was speaking in everyday life, such as greeting, welcoming, complementing, apologizing to customers, and saying goodbye to customers. It was consistent with the research of [2] that most undergraduate students had the speaking skills at the moderate level. Compared to CEFR [8], the speaking skills of RMUTT interns could be defined as basic users. This is because the students had no chance to use English language in everyday life. The lack of practice made the students lack confidence in speaking related to [9] found that the anxiety and the lack of self-confidence hindered them from using English. It is also related to [10] that the English speaking of the homestay owners in Ubon Ratchathani was unclear and difficult to understand, and sometimes made the tourists misunderstand.

1.3 Reading skills of the RMUTT interns were at a moderate level, and the skill with the highest mean was reading emails or business emails. It is because these kinds of materials could be commonly found related to [11] that reading was an English communication skill that was mostly used by reading electronic mails and information from the internet. And it is consistent with [12] media of communication mostly used in Thai workplace was email $(94.4 \%)$

1.4 Writing skills of the RMUTT interns were at a moderate level, and the skill with the highest mean was filling a form. As [13] mentioned, the writing skills were necessary, especially hotel front desk staff, for example, guest registration, filling hotel forms, and taking messages for guests.

2. According to hypothesis tests, the entrepreneurs in the public sector (the government agencies) had the different attitude toward writing skills of the RMUTT interns greater than the entrepreneurs in the private sector and nonprofit organizations. [14] said that writing in the public sector had to be clear and concise and lead to the right results because it involved life-and-death situations.

\section{Recommendations}

\section{A. Recommendations for Practices}

1. The universities should cooperate with the entrepreneurs to improve and develop the curriculum for English language learning covering all 4 skills: listening, speaking, reading, and writing. Also, the curriculum should be up to date to meet the entrepreneurs' needs as well as providing the activities consistent with the future careers and the students' needs. Moreover, the opportunities to use the English language should be provided in order that the students develop and prepare themselves before starting internship, for example, receiving the visiting delegations, English proficiency testing, etc. English language and subject content should be integrated in order to let the students familiar with the terminology.

2. English teaching and learning with the native speakers as well as teaching practical English language skills are great opportunities to practice using English with confidence. The extra English language courses might be provided to support the students' needs. The English language teachers should often update the new teaching techniques. 


\section{B. Recommendations for Further Research}

1. This research was only quantitative research, so conducting the qualitative research for the next research will get more understanding and more practical, such as in-depth interviews.

2. The time before starting the internship or before graduation is limited, so the factor analysis of English language development for interns should be studied to use as a guideline for the students' internship preparation and future careers.

3. Because of getting into the technology disruption era, each curriculum should be re-researched to update the new content and integrate it with English language subjects in order to meet the entrepreneurs' needs.

\section{Conclusion}

In conclusion, according to the research results, many entrepreneurs did not recruit new employees by using the English proficiency test; but from the entrepreneurs' recommendations, they seem to want the competent employees. Moreover, because of technological advancements changing the world, such as ubiquitous commerce, the entrepreneurs are more likely to be multinational or contact more foreign customers. Keeping the students' using English is a simple and effective way to increase their confidence and lower their anxiety

\section{References}

[1] Royal Thai Embassy, Washington D.C., "What is Thailand 4.0", Retrieved on 15th January 2021, from https://thaiembdc.org/thailand-4-0-2/

[2] Y. Yimon, "The Use of English in the Careers of Thai Graduates in Bangkok", Panyapiwat Journal, Vol.5 No.2, pp.191204, 2014.

[3] Rajamangala University of Technology Thanyaburi, "The History of Rajamangala University of Technology Thanyaburi", Retrieved on 15th January 2021, from http://www.eng.rmutt.ac.th/rmutt-history/

[4] J. Richards, "Moving Beyond the Plateau From Intermediate to Advanced Levels in Language Learning", Retrieved on 15th January 2021, from https://www.professorjackrichards.com/wp -content/ uploads/moving-beyond-theplateau.pdf

[5] T. Plailek, "Factors Affecting English Speaking Ability of Second Year English
Major Students in the Faculty of Education, Rajabhat Universities in Bangkok Metropolitan Area", Research and Development Journal, Vol. 3, 2011.

[6] G M. Mîndreci, "Importance of Specialized Languages". in Communication Management Strategies, Vol.4 No.38, pp.278-280, 2017.

[7] T. Phetcharat, "A Survey of English Language Needs for an Evaluation of Materials Used in English Training Courses for Offshore Petroleum Oil Crews", Master's dissertation, Prince of Songkla University, 2012.

[8] Council Of Europe, "Common European Framework Of Reference For Languages: Learning, Teaching”, Assessment Companion Volume With New Descriptors, pp. 34-36, 2018. Retrieved on 15th January 2021, from https://rm.coe.int/cefr-companion-volumewith-new -descriptors-2018/1680787989

[9] S. I. Jahan, and S. A. Shorna, "Speaking Problems In English and Solutions:Scrutinizing Students' Perspective." Shanlax International Journal of English, vol. 8, no. 1, pp. 3441, 2019.

[10] P. Saiduang \& C. Pitikornpuangpetch, "The Study on the Needs of English Language Communication for Conservative Tourism of Homestay Tourism Groups: A Case Study of Ban Sasom Village, Khong Chiam District, Ubon Ratchathani Province", Humanities and Social Sciences Journal, Ubon Ratchathani Rajabhat University, vol. 8 no.1, pp.284-300, 2017.

[11] K Kosashunhanan, "The Use of English for Communication by Thai Engineers: Case Study of Japanese Companies at Amata Nakorn Industrial Estate", Suthiparithat, vol.30 no.93, pp.146-159, 2016.

[12] K. Hiranburana, "Use of English in the Thai Workplace", Kasetsart Journal of Social Sciences, 38, pp.31-38, 2017. 
[13] S. Kalasin, "Needs and Problems of English Use among Thai Hotel Front Desk Staff in Tourist Attractions of Southern Thailand", Master's dissertation, Prince of Songkla University, 2013.

[14] J. W. Swain \& K. D. Swain, "Effective Writing in the Public Sector", Routledge, New York, 2015. 